\title{
CURRICULUM DEVELOPMENT IN SCIENCE - PAST, PRESENT AND FUTURE
}

\author{
Peter E. Childs \\ Chemistry Education Research Group, Dept. of Chemical and Environmental Sciences and National \\ Centre for Excellence in Mathematics and Science Teaching and Learning, University of Limerick, \\ Limerick, Ireland • peter.childs@ul.ie
}

\begin{abstract}
Science only became a recognised school subject at the end of the $19^{\text {th }}$ century. The study of science subjects remained an elitist pursuit until the mid-late $20^{\text {th }}$ century, but it is now seen as a core subject in many countries, especially in the junior secondary cycle. Since the 1950s there have been major reforms in science education - in the USA, UK and other countries - with a shift away from a focus on content and prescribed practical work, to emphases on inquiry (thinking and working like scientists) and the social aspects of science (in the STS and context-based movements) and on the nature of science (history and philosophy of science). The talk will trace the evolution of the school science curriculum, with a focus on the UK and Ireland, and in particular the changing fortunes of discovery/inquiry science, whose latest incarnation - inquiry-based science education IBSE), is currently in vogue, particularly in Europe. Different science curricula have had different balances between the needs of science and scientists, of students, and of society. In addition, there have been at least three main paradigms underlying school science curricula:

the facts and concepts of science (content);

the nature and processes of science (conduct or process);

the applications of science in society (context).

Modern curricula rightly consider that all these aspects are important, although each one has produced its own version of school science, where its emphasis is dominant. The prevailing trend is to integrate all three aspects into science curricula, whether as combined science or single sciences, designed both for the needs of future science specialists and for citizens. Apart from the social and economic demands on science curricula to deliver benefits for society and the economy, the other major influence in the last 40 years or so has been the growth of science education research, and the demand that reforms in science curricula and classroom practice be evidence-based.
\end{abstract}

It is in fact nothing short of a miracle that the modern methods of instruction have not yet entirely strangled the holy curiosity of inquiry; for this delicate little plant, aside from stimulation, stands mainly in need of freedom.

Albert Einstein

\section{Introduction}

The quotation above can serve as a theme for this article. How can modern science education avoid killing the interest and curiosity in children that it seeks to nurture and develop? The overall aims of this article are to:

To trace the development of science/chemistry as a school subject from the $19^{\text {th }}$ century to today. To consider some of the issues, problems, questions and influences relating to the science/chemistry curriculum. I have four main messages, which I hope to develop in this article: 
- The chemistry/science curriculum needs a balance of all the main themes/emphases: content, process and context.

- All aspects of the curriculum - content, pedagogy, outcomes and assessment must be integrated with each other and informed by science education research.

- The curriculum must meet the needs of the majority (scientific literacy for future citizens) and also for the minority (science foundation for future scientists).

- Curriculum development must involve teachers, scientists and science education researchers.

\subsection{First some caveats}

This is a personal view with a bias towards Anglophone countries - UK, Ireland and USA, reflecting my own experience; it is a broad brush treatment of a large and complex area; it reflects my own interests, expertise and ignorance and is thus necessarily limited in perspective. There are many people far more qualified than me to speak on this topic, but my claim to look at it is based on my experience of teaching chemistry at university level for nearly 40 years, my involvement with chemistry teachers and chemical education over many years, and the fact that my own chemical education has covered a period where there has been dramatic change.

\subsection{A personal perspective on my career in chemical education in 3 countries}

I was brought up the U.K. and went through the O-level system (maths, chemistry and physics) (1958), I studied A-level Chemistry (1960), along with maths and physics, and was taught by traditional, didactic means from traditional syllabi (NUJM). I then took a bachelor's degree in chemistry (1965) followed by a DPhil in solid state chemistry (1967) at (Oxford). I then spent two years at Northwestern University, Evanston, USA as a postdoc on a Fulbright Fellowship.

My university teaching career started in Uganda at Makerere University, Kampala (19701976). Uganda offered O and A levels and the university offered a typical content-based threeyear degree, based on the UK model. While there I started my involvement with chemistry teachers: helping run a conference on 'A Modern Approach to Teaching Chemistry' (1971) to introduce a new A level chemistry course, starting a chemistry teacher's newsletter and setting A level papers. The $\mathrm{O}$ and A level chemistry courses were traditional content-based courses but there was a pilot East African Science Project, based on the Nuffield courses. After a short break in the UK on research fellowships I moved to Ireland in 1978 to teach chemistry at Thomond College of Education (TCE) to pre-service science teachers (PSSTs), together with chemical education. My involvement with chemistry teachers and PSSTs became more important and I was involved in a number of activities: starting Chemistry in Action! magazine (1980-), starting the annual ChemEd-Ireland conferences (1982), running in-service courses and workshops, curriculum development in the TY Science project (2003-), doing research in chemical education with both undergraduates and postgraduates; 
and setting up the Chemistry Education Research Group. The science and chemistry syllabi in Ireland have changed several times since 1978, and have shown a gradual change from traditional, content-based courses to inquiry-based courses in the latest revision. TCE merged with the University of Limerick in 1991 and I joined the chemistry department and spent most of my time teaching inorganic and environmental chemistry to undergraduates, including PSSTs, and supervising teaching practice and final year projects. This experience as a chemistry student, chemistry lecturer and researcher in several countries has given me an overview of the way chemical/science education has changed over the last 50 years, since I took my first chemistry course in school.

\section{Some Questions about the Science Curriculum}

When we think about the school science curriculum and the way it has developed over the last 150 years or so, it raises many questions about the content and purpose of the science curriculum.

\subsection{What do we mean by the science curriculum?}

The idea of Curriculum can be applied to the whole school programme or to a specific subject. When we apply the term to the science/chemistry curriculum it refers to all the components/aspects of a course (Figure 1):

- Content

- Pedagogy

- Aims \& Outcomes

- Assessment

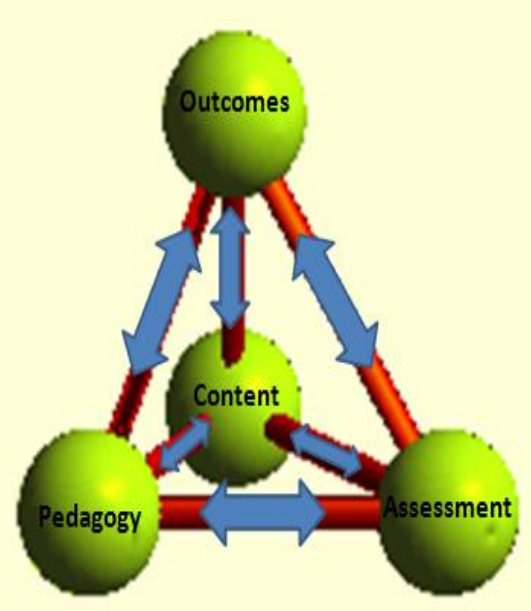

Figure 1 The four aspects or dimensions of the science curriulum

Each of these aspects is important and they all interact with each other and none of them can be ignored. In the past the main focus was on the content of a course and the subject matter, and the current focus has shifted to pedagogy with an emphasis on inquiry-based science education (IBSE). The evolution of school science education over the years has led to the recognition that all these aspects matter and must be in harmony with each other. 


\subsection{Curriculum development - what is it?}

A recent review of 50 years of curriculum development by Tomei (2012) came to this conclusion:

We use the term "Curriculum development" as if it were a single entity, but in fact it covers a wide range of activities such as:

- shaping the curriculum itself, (that is to say the topics and their coverage);

- developing the resources to help teach these topics;

- the guidance for teachers in using the resources or conducting lessons (i.e. pedagogy);

- developing different approaches to assessment; and

- the research that underpins all these activities.

When we look at the science/chemistry curriculum in any country we have to ask about the origins of school science. When school science education started depends on the specific country, but it often started as personal or individual school initiatives in the mid $19^{\text {th }}$ century, rather than as a state-sponsored project.

Science can be taught at primary (elementary) level or post-primary (secondary) level, and the first initiatives in teaching science often started in primary schools. The school curriculum in secondary schools was dominated by a traditional structure based on the Classics (Greek and Latin), and had been originally designed to produce clerics and office clerks. Science was only made an official part of the secondary school curriculum in the late $19^{\text {th }}$ century or start of the $20^{\text {th }}$ century. Major curriculum change did not start until after WW II (1945) and science was still seen as an elitist subject for a few, rather than as science for all, until the last quarter of the $20^{\text {th }}$ century. In fact even in the early $20^{\text {th }}$ century science was 'the new kid on the block' in schools, with none of the tradition and prestige attached to traditional core subjects, such as the classics and mathematics. This means that science teaching at school in most countries has a history of less than 200 years, and much less as an essential part of the curriculum! As a relative newcomer in the school curriculum, science had to fight for a place in schools in the late $19^{\text {th }}$ and early $20^{\text {th }}$ century, just as it had to do in the universities. It is a sign of how far we have come, that now science is considered an essential part of the school curriculum for all students, at both primary and secondary level.

\section{When did science education start as a formal subject?}

W.H. Brock (1979, p. 68) takes 1839 as his starting point:

My starting date, 1839 , is arbitrary. It is the year in which the German chemist Liebig moved into an enlarged laboratory at Giessen, enabling him to expand the output of students. We may take this as a symbolic starting point for the development of modern science education.

Figure 2 shows Liebig's Laboratory in Geissen, Germany. Liebig's main contribution to teaching chemistry was to put original research at the heart of chemical education for professional chemists. Many of the influential chemists and chemical educators in the UK, for example, in the $19^{\text {th }}$ century, like Henry Armstrong, came through Liebig's hands. Brock 
(1992) has given a helpful survey on the development of chemical education in his Fontana History of Chemistry. Formal chemical education started in the universities and only later filtered down into schools. But from the mid 1800 s more and more secondary schools were teaching science as a part of the curriculum. One interesting feature of chemical education in England in the $19^{\text {th }}$ century is how many important scientists started teaching in schools and moved on into universities, and how influential they were in deciding what should be taught in schools. John Dalton started life as a school teacher, as did Edward Frankland and John Tyndall.

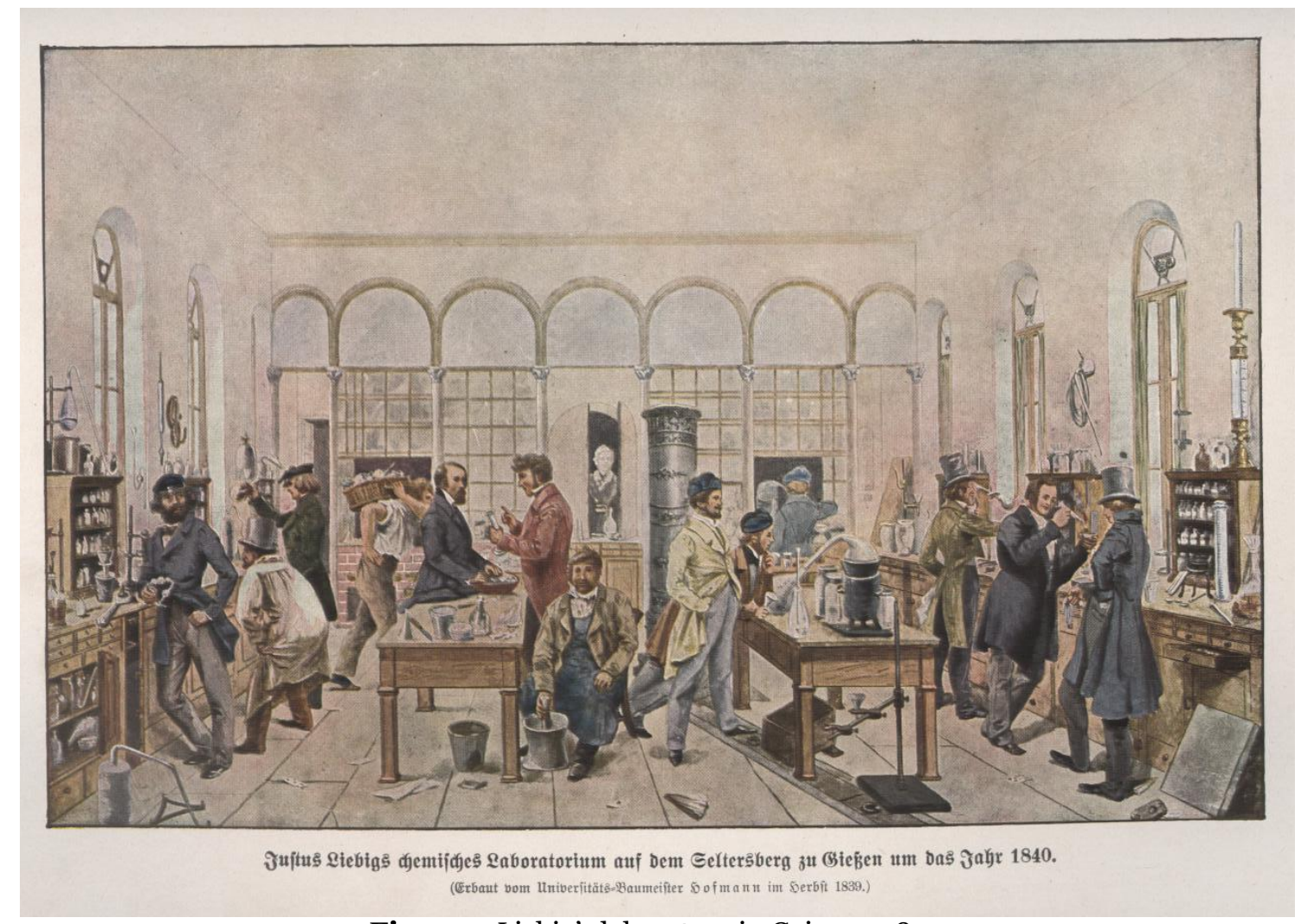

Figure 2 Liebig's laboratory in Geissen, 1840

\subsection{School science in the UK (Ireland)}

Science started in elementary (primary) schools mid-180os, but was then banished until the early $20^{\text {th }}$ century. Secondary science began in the late 1850 os in the UK (e.g. Bristol 1856 and Rugby 1860) and in Ireland in 1874. (England and Ireland were part of the same country until 1922, and although they had different education systems, there was much interchange and overlap.) Edward Frankland's control of the school examination system in England allowed him to insist on teachers demonstrating a mandatory set of experiments to their pupils (from 1871), leading to a proliferation of school laboratories. Brock comments (ibid, p. 405). 'This is the origin of the strong tradition of science teacher demonstrations that remains in British practice."

Science was only formalised in the secondary curriculum much later in England in 1904, although it came earlier in Ireland in 1878. Primary science was only made compulsory in 
1989 in England and in 2003 in Ireland, despite the fact that it had first been introduced in the mid $19^{\text {th }}$ century. In Ireland science was displaced by Irish in primary (national) schools in the 1930 s and it took over 70 years for it to recover its place in the primary curriculum.

Surprisingly, compulsory secondary science to age 16 in UK was only introduced in1988. Secondary science is still not compulsory in Ireland, even though $\sim 90 \%$ take it in the lower secondary cycle. For the history of science teaching in the UK, see Adey (2001), and in Ireland see Wallace (1972). Though both accounts are interesting they are both now out-of-date. Goodson and Marsh (1996) have a useful chapter on science as a school subject in their book Studying School Subjects: A Guide.

The history of science as a school subject and curriculum development in science is complex and country-specific, and there would be value in a series of comparative and reflective case studies looking at the way science education has developed in different countries.

\subsection{What is science education?}

The most recent statement about science in the 'National Curriculum in England' describes what is understood by science education (National Curriculum in England, 2013).

A high-quality science education provides the foundations for understanding the world through the specific disciplines of biology, chemistry and physics. Science has changed our lives and is vital to the world's future prosperity, and all pupils should be taught essential aspects of the knowledge, methods, processes and uses of science. Through building up a body of key foundational knowledge and concepts, pupils should be encouraged to recognise the power of rational explanation and develop a sense of excitement and curiosity about natural phenomena. They should be encouraged to understand how science can be used to explain what is occurring, predict how things will behave, and analyse causes.

This reflects the contemporary view of school science education, although this view has changed considerably over the years. In a recent report on science education in New Zealand (Gluckman, 2011), four purposes of science education are identified. These are:

1. Preparing students for a career in science (professional purpose).

2. Equipping students with practical knowledge of how things work (utilitarian purpose).

3. Building students' science literacy to enable informed participation in sciencerelated debates and issues (democratic/citizenship purpose).

4. Developing students' skills in scientific thinking and their knowledge of science as part of their intellectual enculturation (cultural/intellectual purpose).

\section{Curriculum emphases in science education}

Over the years of the evolution of school science, there has been a change in the emphasis and purpose of the curriculum. Roberts (1982) defined a 'curriculum emphasis' in this way: 
A curriculum emphasis in science education is a coherent set of messages to the student about science (rather than within science). Such messages constitute objectives which go beyond learning the facts, principles, laws, and theories of the subject matter itself - objectives which provide answers to the student question: 'Why am I learning this?'

One of the reasons for the different science curricula over time or the differences between countries or between levels of education, is a difference is what are considered to be the important curriculum emphases. Roberts (1982) identified seven in his review, although these will not be found in every science curriculum:

- Everyday Coping;

- Structure of Science;

- Science, Technology, and Decisions;

- Scientific Skill Development;

- Correct Explanation;

- Self as Explainer; and

- Solid Foundation

It can be argued that Roberts' seven emphases are too many to be practicable and so several reduced versions have been proposed. Van Berkel proposed 'Three Curriculum Emphases' for school chemistry (Van Berkel, 2005). These were:

- Fundamental Chemistry (FC)

- Knowledge Development in Chemistry (KDC)

- Chemistry, Technology and Society (CTS)

Jonathan Osborne's triumvirate of emphases (Osborne, 2007) are similar to Van Berkel but phrased more simply and provide a useful working framework. Osborne proposed the following main curriculum emphases:

- Scientific content

- Scientific approach to enquiry

- Science as a social enterprise

\subsection{The Bandwagon rhetoric}

Curriculum development in science, as in other subjects, is subject to fads and fashions, which change over time.

Once a curriculum emphasis comes into vogue it suffuses textbooks, teacher preparation programs, schools, and-above all teacher thinking...Once a significant amount of support develops for the new emphasis (as seems to be happening now for Science, Technology, and Decisions), the usual demeanour of educational rhetoric is to cast the chosen emphasis as "good" and "modern" and "innovative," while all others are "inadequate" and "traditional" and "out of date." The implications for practice which flow from such bandwagon rhetoric suggest throwing out the baby with the bathwater-i.e., excising all remnants of the older emphases from textbooks, teacher education programs, etc. (Roberts, 1982, p. 256-257) 
Teachers and curriculum developers are under pressure from 'the spirit of the age' to adopt the latest paradigm or method or technology, and to jump on the latest educational bandwagon. "Teachers call it the "reform du jour," and for many, it's the biggest challenge at the start of any school year. That's when the latest idea for how to improve student performance kicks in.” (Chaddock, 1998)

A recent example of this is the rush to make inquiry-based science education (IBSE) the main method of teaching science in schools, which has been heavily promoted by the European Commission after the Rocard Report (2007). The danger of educational fads has been exposed by Elder and Paul (2007) in their book A Critical Thinker's Guide to Educational Fads and the evidence base for fashionable educational ideas has been assessed by Hattie (2008) in his book Visible Learning. The history of curriculum development is of one fad after the other, with a lifetime of $\sim 20$ years.

\subsection{What should constitute science education?}

There seems now to be broad agreement on three main emphases or themes in school science education, which I have simplified further (see Figure 3):

- Content - pure laboratory science What?

- Process - the way science is done How?

- Context - applications \& relevance Why?

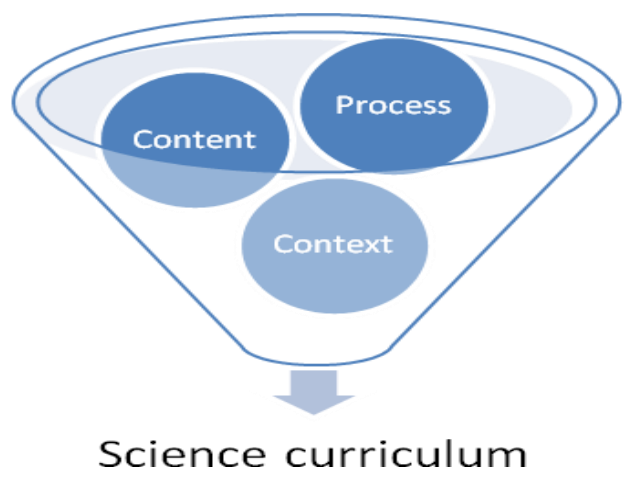

Figure 3 The three main emphases in the science curriculum

There is now a general recognition, I think, that all three main emphases are needed, but different science curricula have had, and still have, a varying balance of these three. Depending on the course aim, the specific country, and the age and ability of the students, the mix of these three components has varied over time. For example, for older, higher ability, science specialists in many countries the dominant emphasis has been on content. This is what I experienced in the late 1950s in England and in the 1970s in Uganda. On the other hand, for younger, lower ability, non-specialists the emphasis has often been on context and process. In primary science the focus has been almost exclusively on process, particularly on inquiry. 


\section{The evolution of science education 1840-2014}

I will look briefly at the development of each of the three emphases over the years, mainly in the UK and Ireland. This is country-specific but you should reflect on the situation in your own country:

- When did science start in schools - primary and secondary?

- What was the purpose of science education?

- Who was it for?

- What sort of science was taught?

- What were its aims and purposes?

\subsection{Content: the 'what of science' or 'Education in science'}

The focus here is on content and this was the dominant approach in school science curricula up to the 1960s. Liebig's model of pure laboratory science influenced university science across Europe and filtered down to school level.

The ideal of the research school [Liebig] founded there, (i.e. in Giessen) which later was to attract large numbers of young British scientists, was research and inquiry for its own sake. This provided the concept of 'pure laboratory science; which was to dominate school science curricula especially for the more able children, throughout modern time.” (Hodson, 1988, p. 141)

Science was seen as a subject for the higher social classes and higher ability pupils.

The purpose of secondary science education was to prepare students for university and careers in science and the curriculum was determined by university scientists. Theese were the features of 'Pure laboratory science':

- Focus was on the 'what' of science - facts, concepts, principles and lab skills.

- Purpose was to produce future scientists, an elite group.

- Textbooks were watered-down university textbooks.

- Heavy emphasis on gaining practical laboratory skills through routine, repetitive

- practical work.

- Content dictated from above (top-down).

\subsubsection{The top-down curriculum}

In England in the second half of the $19^{\text {th }}$ century a political, social and cultural battle resulted in a victory for a top-down science curriculum, designed for the ruling elite and dictated by universities. Goodson and Marsh (1996, p. 73) comment:

The consequence of accepting that science would henceforth be essentially defined in universities was potentially devastating for a school science developed for a mass education. The handover of control and the narrowing and abstraction of the discourse often put science beyond the realm and language of understanding of ordinary children and indeed ordinary people.

This was the nature of the science curriculum being taught in English grammar schools in the 1950 os and 6os when I went through the system, and the school examinations were set and marked by examination boards run by consortia of universities. 


\subsection{Process: the 'why of science' - Education through science'}

In this emphasis the focus is on the skills and methods of science (learning through science), and has encompassed a number of different themes over the years:

- Discovery learning (Heurism)

- Inquiry-Based Science Education (IBSE)

- Nature of Science (NoS)

- Philosophy of Science (PS)

The contemporary emphasis on IBSE might make one think that this was a new idea. One of the pioneers of this approach, which became known as heurism, was Henry Armstrong (1819), an English Professor of Chemistry who saw the weaknesses of school science in the students he taught. From 1884 he wrote and spoke about his idea of teaching science by doing science, and implemented the ideas in his own college teaching and encouraged its adoption in schools.

If boys and girls left school properly aware what an experiment is, what is involved in making one, how far from easy it is to make a real experiment; if they acquired a true sense of exactness in work and argument: the teaching given in schools would be of great value in after-life, as life is one big never-ending experiment. I see no reason why there should be school laboratories if the main purpose of them be not to give training in the art of inquiry. (Armstrong, 1925, p. ix)

This was the origin in the UK of 'discovery learning' in science education, which through its nurture in schools like Christ's Hospital, and influential teachers like Charles Brown and Gordon von Praagh, resulted in the Nuffield Science projects of the late 1950 os and later.

\subsection{Context: the 'why of science' - 'Education about science'}

The focus here is on the context and applications of science and their relevance to the student's everyday life. This also seems to be very contemporary emphasis when we think of context-based courses like Salters Chemistry and Chemistry in Context. However, this emphasis also has a long history and one important example, although ultimately unsuccessful, was 'The Science of Common Things' promoted by Richard Dawes, 1840-60 a short-lived initiative in some English country schools. This was a 'science for all' programme, started in rural elementary (primary) schools by an educational enthusiast (see Ball, 1994 and Layton, 1973). The initiative was squashed around 1860 and primary science had to wait almost a hundred years to be re-introduced.

This emphasis on application, relevance and context was not recovered until the 1970s and 8os, with the Science, Technology and Society (STS) courses from the 1970 s and Contextbased Learning (CBL) 1980s: for example, in the UK the Salters science courses (1986 -) and $21^{\text {st }}$ Century Science (2003); ChemCom (1981) and Chemistry in Context (1989) in the USA and In Germany Chemie in Kontext (1997). Ratcliffe (2001) has given a helpful overview of the development of STS courses. Bennett and Lubben (2006) have described the Salters approach to context-based chemistry. 
The context-based courses developed the chemistry/science content starting from a chemistry/science context, and in so doing reversed the traditional order of teaching.

In the traditional chemistry course: chemistry content $\rightarrow$ chemical context and here the focus was on the facts and theories of science and the applications, contexts and relevance were added on at the end as illustrations. So for example a treatment of the atom and radioactivity eventually ends up with nuclear power and uses of radioactivity.

In a context-based chemistry course: chemical context $\rightarrow$ chemistry content, and in these courses the chemical context is the starting point for the topic and the relevant chemical content is introduced to support and explain the context. For example, a consideration of climate change leads to the treatment of the atmosphere, combustion and fossil fuels, spectroscopy and stoichiometry.

\section{Three waves of curriculum development in science}

As we look back at the recent history of curriculum development in chemistry/science, and using a broad brush, we can identify three waves or phases. All of these came after I finished studying chemistry at school, but I have been a keen observer and participant in chemical education since then.

\subsection{0/70s CBA, ChemStudy, Nuffield Chemistry}

The emphasis was on the structure of the discipline and content - the courses were aimed at an elite, those students who would become future scientists. This was chemistry for future chemists. The main focus was on the content and structure of the subject. The Nuffield courses did emphasise discovery learning but the focus was still on academic rigour in the A level and O level courses.

\subsection{0/90s Context-based chemistry (ChemCom, Salters Chemistry, Chemie in Kontext)}

The emphasis was on scientific literacy and science/chemistry for all and the needs of all future citizens. Thus the courses focused on the context and social aspects of science, and its relevance to everyday life. This phase also included courses with a Science-TechnologySociety (STS) focus, which predated the context-based courses.

\subsection{0/10s: Inquiry-based science education (IBSE) and process skills}

Since the start of the $21^{\text {st }}$ century there has been an emphasis on what are called $21^{\text {st }}$ century skills, with science for all students. This focus has been promoted by the European Commission through the FP7 Science and Society projects, following the Rocard Report (2007). Dozens of IBSE projects have been funded in the last 10 years or so. The focus of these projects and many new courses is on process and inquiry skills, although there is still attention to content and to context.

These three emphases have overlapped and are present in different degrees in the different courses. 


\section{Some broad concerns about and trends in science curricula}

There are a number of issues, concerns and trends in contemporary science education which have arisen over the past few decades, and a few of these are briefly mentioned here.

\subsection{An overloaded curriculum}

When revising science curricula there has been a tendency to include more and more content in order to keep up with developments in science, without leaving out the older material. This presents the danger of having breadth of coverage without depth of treatment.

\subsection{Mismatch between curriculum aims and teachers' practice}

It is often said that "Teachers teach how they were taught NOT how they were taught to teach" - or how the new curriculum expects them to teach. There is often a difference between the prescribed curriculum, the taught curriculum and the assessed curriculum, although the aim is to have them all in harmony. It is well established that changing a teacher's practice and the educational culture is a difficult job - like turning round a supertanker! For example, all the talk and emphasis on inquiry has not been reflected in a major change in the way science is taught outside the pilot project schools. Many curriculum reforms have a short lifetime and often leave little impression on science education.

\subsection{From elite to mass education}

Since 1960 the percentage of the age cohort staying on at school after the age of compulsory schooling and entering third level has increased dramatically in most countries, in what has been called the 'massification' of higher education. For example in the UK in 1960, O and A levels were taken by the top 10-20\%, there were more girls than boys doing science, and for the majority very little science at all. Science is now done by everyone to age 16 although only 18\% of a reduced A-level cohort take science A levels (in 2013). The recent Royal Society Vision Report (Royal Society, 2014) recommends that all U.K. students take mathematics and science to age 18, as the majority drop these subjects at age 16. In Ireland, by contrast, although science is not compulsory in secondary education, 90\% take the lower secondary science course and over $60 \%$ take at least one science subject in the senior cycle and $95 \%$ take mathematics. Over $90 \%$ of students now stay on in Ireland to the end of secondary education (age 17/18) and over 60\% go on to third level. This expansion of senior secondary and tertiary education has meant a much wider spread of ability in science classes. In Ireland this is partly allowed for by offering all senior cycle subjects, including the science subjects, at higher and ordinary levels.

\subsection{Dumbing down?}

As a consequence to the broadening of science intakes, there has been a concern that standards have dropped to cater for the wider range of ability. The content and style of chemistry curricula has changed and despite increasing numbers of students, with a wider range of ability, examination grades have climbed steadily in both the UK and Ireland. This 
has led to concern from university academics especially, about grade inflation at school and also at third level - we have larger numbers, with a much greater ability spread but yet higher grades and better degrees!

\subsection{Challenge of interdisciplinarity}

Traditionally science was taught as separate disciplines, especially at the higher levels (senior secondary). Students and their teachers have tended to work in subject bunkers, with little collaboration between subjects and some duplication and overlap of courses e.g. atomic structure in physics and chemistry. But real-world problems are messy, complex and multidisciplinary e.g. climate change. This leads me to ask whether a narrow, subject-based school science education is fitting students for the real world or not? Even when junior secondary cycle courses are usually general science, there is often little integration of the different sciences and they are taught in separate strands, sometimes by different teachers.

\subsection{Lack of resources for teaching science}

The perennial complaint of science teachers is that there is a lack of resources and poor infrastructure for science in schools - in laboratories, technical help and ICT provision, to enable them to do the job properly and deliver a modern approach to teaching science. For example, many school chemistry syllabi include instrumental methods (e.g. UK A levels and Irish senior cycle chemistry) but very few schools have such instrumentation. The move to science for all and greater participation in science at school has major implications for resources, facilities and enough qualified teachers. There is concern in some countries e.g. the U.K., about a shortage of specialist teachers of physics and chemistry.

\subsection{Quality of initial and continuing teacher education}

There is widespread concern that initial science teacher training courses are too short and that there is too much to cover, whether they are 4 year concurrent or 1-2 year consecutive courses. The common complain of teacher educators is: "So much to do, so little time to do it”. There is also a complaint that continuing professional development (CPD) is inadequate - underfunded, lacking long-term planning or career structure, and too short. Initial teacher education can never be adequate to equip teachers for a career spanning up to 40 years, and regular CPD is essential. The main criticism of attempts at curriculum reform is that there has been inadequate training and support for teachers.

\subsection{Lack of involvement of teachers in curriculum reform}

Often science curricula are determined and designed from above, in a top-down approach, with little real involvement by practising teachers. Initially universities through their matriculation (examination) boards had the main influence. Curriculum projects involve teachers but usually these are the enthusiasts. Many science curricula fail because they do not carry the teachers with them and teachers feel they have no ownership or real input into 
curriculum development. This raises the question, covered in the next section: who decides the science curriculum?

\section{Who decides the science curriculum?}

The nature of the science curriculum in any country is determined to a greater or lesser extent by who decides what it is. This has changed over the years and is different in different countries:

- The church (up to the mid or late $19^{\text {th }}$ century).

- Individuals $\left(19^{\text {th }}\right.$ century - local initiatives e.g. Richard Dawes, H. E. Armstrong).

- Universities (early $20^{\text {th }}$ century onwards - examination boards).

- The State $\left(20^{\text {th }}\right.$ century onwards in many countries e.g. National Curriculum in the

- UK).

- Charitable Foundations in some countries (e.g. NSF, Nuffield, Salters - 1960s onwards) - funding curriculum innovation projects.

The most common model worldwide is now State control. In most countries the science curriculum is determined centrally by the Ministry of Education or a national curriculum body e.g. in Ireland the National Council for Curriculum and Assessment (NCCA). This may be done at the level of the country as a whole, or within the country at the level of individual states or regions (e.g. Lander in Germany, States in the USA or cantons Switzerland). Such curricula are often top-down, centrally controlled and examined, and apply to everyone. There is a danger of 'one size fits all', i.e. everyone has to take the same chemistry syllabus, and hence a lack of competition and innovation. This is the case in Ireland where all curricula are designed by a government body (NCCA), which advises the Minister of Education, and there is no choice of syllabus in any subject, only a choice of ordinary or higher level. In some countries e.g. USA (AAAS, NRC, NSF) and UK (Nuffield, Salters, Horners) the system allows other bodies to develop and promote alternative curricula, using money from private foundations. This allows for innovation and experimentation in developing science curricula with different emphases and this model has been very influential in the development of novel school science curricula.

\section{What sort of science should we teach?}

The question of what science is taught and how it is taught has changed and evolved over the years and is still a matter of live debate. (See the report Science Education in Europe: National Practices, Policies, and Research (Eurydice, 2011) for recent comparative survey of the way science is taught in Europe.) For example, should we teach some form of General/Combined/Integrated science $(\mathrm{B}+\mathrm{C}+\mathrm{P})$ or single subject science $(\mathrm{B}, \mathrm{C}$ or $\mathrm{P})$ in the lower secondary school? The way this has evolved during the 2oth century into the 21st century, is that general science of some sort is taught in primary and junior secondary schools (years/grades 1 to 9/10), where the whole school population is involved and often (but not 
always), science is a compulsory subject. In senior secondary school (years/grades 10/11-12), single science subjects are usually taught (usually B, C or P). (In the U.K. there is also an option to take single science subjects in middle/junior secondary school, a return to the old O-level pattern.)

When general science is taught for all students there are several options: in parallel (e.g. UK, Ireland, IB); integrated or combined; or sequential (USA - B, C, P are taught in successive years). Herr (2008, p. 503) gives an interesting comparison of secondary science in China versus the USA.

The Chinese science curriculum is uniform, narrow and deep, while the American curriculum is varied, broad and flat. The Chinese curriculum is vertical and spiral in nature - the same science concepts and skills appear again and again in the curricular materials at different levels of schooling, with greater knowledge and deeper understandings at the higher level.

The Chinese school curriculum contains much more science, it is taught in every year and all three sciences are covered. In the USA, the single sciences are taught once, in successive years, and not to any great depth. As Herr (2008, p. 502-3) quotes: "The US science and math curriculum is 'a mile wide and an inch deep."'

\subsection{How do we avoid following the latest fads?}

Fads come and go in education, especially in educational technology, without any real evaluation of the evidence. Chaddock (1998) commented:

Teachers call it the "reform du jour," and for many, it's the biggest challenge at the start of any school year. That's when the latest idea for how to improve student performance kicks in.

A current example of this is the headlong rush towards IBSE, which I term the Rocard Effect, after the Rocard Report (2007), which has been highly influential in Europe in directing almost all the science education grants in FP6 and FP7 into dozens of Inquiry-Based Science Education projects (see http://www.scientix.eu/web/guest/home), based on its claim for the proven efficacy of this approach.

A reversal of school science-teaching pedagogy from mainly deductive to inquiry-based methods provides the means to increase interest in science. Inquiry-based science education (IBSE) has proved its efficacy at both primary and secondary levels in increasing children's and student's interest and attainment levels while at the same time stimulating teacher motivation. (Rocard Report, 2007)

However, the meta-analysis of research studies by John Hattie (Hattie, 2009) does not rank inquiry-based teaching as one of the top 20 strategies for improving student learning and the work by Coburn et al. (2010) showed no significant difference between inquiry and direct instruction in science. So maybe we should not put all our eggs in the same IBSE basket.

There have been many competing ideas and paradigms and strategies over the years in science curricula, all claiming to be the silver bullet that will solve all problems, and teachers and governments continue to jump onto the various bandwagons: HOCS, NoS, IBSE, CBL, Peer learning/teaching, Concept maps, Learning styles, CAL, PBL etc. etc. What we need, 
rather than an exclusive focus on one approach, as with IBSE, is an eclectic and inclusive approach, which draws on the various methods as appropriate, in the teaching and learning context.

\section{The future of STEM education}

Science education has now been subsumed into a broader concern for STEM education: science, technology, engineering, and mathematics, recognising the interdependent nature of these disciplines. The nature of STEM education is still a live issue in many countries in 2014, despite many decades of curriculum reform, and science education research, and various teaching and learning approaches:

- What should we teach?

- How should we teach?

- Who should we teach?

- Why should we teach?

One would have thought that given the number of national and international reports published since 2000, that there would be by now a clear vision of what science education should be in the $21^{\text {st }}$ century, and a programme of how to get there, all supported by research evidence. However, it seems that the many questions are still not settled and the solutions have certainly not put been put into practice, as evidenced by the many STEM reports still issuing from many countries e.g. the USA (NRC, 2012), UK (RSC, 2011; National Science Learning Centre, 2013; The Royal Society, 2014), New Zealand (Royal Society of New Zealand, 2012), Ireland (STEM Review Report due early 2015).

\subsection{Problems of curriculum change}

Much of the curriculum change that has occurred in science since 1960 has been unsuccessful in the long term, in not having any real effect on what is taught in the classroom, and the effects have largely been localised and short-lived. As Matthews commented in 1994, curriculum change alone is not enough to change the system (my emphasis).

.. although curriculum is important it is not important in itself: the mere change of curriculum, without change of teacher education, assessment tasks, resources and support, is not going to have any dramatic effect on student engagement, interest and learning of science or any other subject. It is of little use to set up high-powered curriculum committees that devise curricula which are then sent by mail to schools. Curriculum without appropriate texts, examinations, teacher commitments and systematic support is like a car without petrol - it looks nice but it doesn't go anywhere. (Matthews, 1994, p.20)

\subsection{Are ' $21^{\text {st }}$ Century Skills' the answer?}

The recent discussion of STEM education has been highly critical of the way science has and is being taught in schools, as both a poor preparation for further study but also as poor preparation for work in the $21^{\text {st }}$ century, and so the call has been for STEM subjects to embrace $21^{\text {st }}$ century skills. 
While scientists passionately explore, reason, discover, synthesize, compare, contrast, and connect the dots, students drudgingly memorize, watch, and passively consume. Students are exercising the wrong muscle. An infusion of STEM taught in compelling ways will give students an opportunity to acquire these active learning skills.

The skills of the 21st century need us to create scholars who can link the unlinkable.... Nurturing curious, creative problem solvers who can master the art of figuring things out will make them ready for this unknown brave new world. And that is the best legacy we can possibly leave. (Ramirez, 2013)

This call for $21^{\text {st }}$ century skills is definitely in fashion and in tune with the spirit of the times, but it has also been criticised as being a new setting of an old tune, which many would claim has failed in the past, of process over content, skills over subject knowledge (Ravitch, 2015) For the past century, our schools of education have obsessed over critical thinking skills, projects, cooperative learning, experiential learning, and so on. But they have paid precious little attention to the disciplinary knowledge that young people need to make sense of the world.

This deeply ingrained suspicion - hostility, even - towards subject matter is the single most significant reason for the failure of the standards movement in American education over the past generation.

We should have been educating future teachers to study their subject or subjects in depth. We should have paid attention to what Lee Shulman, educational psychologist and professor emeritus at Stanford, calls "pedagogical content knowledge." We should have been helping teachers determine ways to light up young minds and to generate excitement about historical imagination or scientific discovery.

\section{Conclusion}

The battle between two opposing viewpoints on the nature of science education, emphasising on one hand science and on the other hand education, was apparent when the general science curriculum, $21^{\text {st }}$ Century Science, was introduced in the UK in 2006. When it was introduced, the new course (part of a suite of GCSE courses,

http://www.nuffieldfoundation.org/twenty-first-century-science) was denounced as by some scientists as dumbing-down science, with its focus on everyday issues and scientific literacy. However, as this course has become established in the secondary system, the evidence shows that this course is very successful in attracting young people into science and keeping them there. (Millar, 2009)

We seem doomed to repeat the mistakes of the past, refighting battles, which in some cases go back over a century:

- Educationalists versus science specialists

- Process versus content

- Skills versus knowledge 
- Specialist versus generalist

- Pure versus applied etc.

However, what I want to say in conclusion, after this 'mile wide and inch deep' review of the history of science education, is that the answer is not either/or but both/and: we need to include all the three themes in our science education (content, context and process) (see Figure 4) and we need to use a variety of teaching and learning approaches and we need to learn from and apply the findings of science education research.

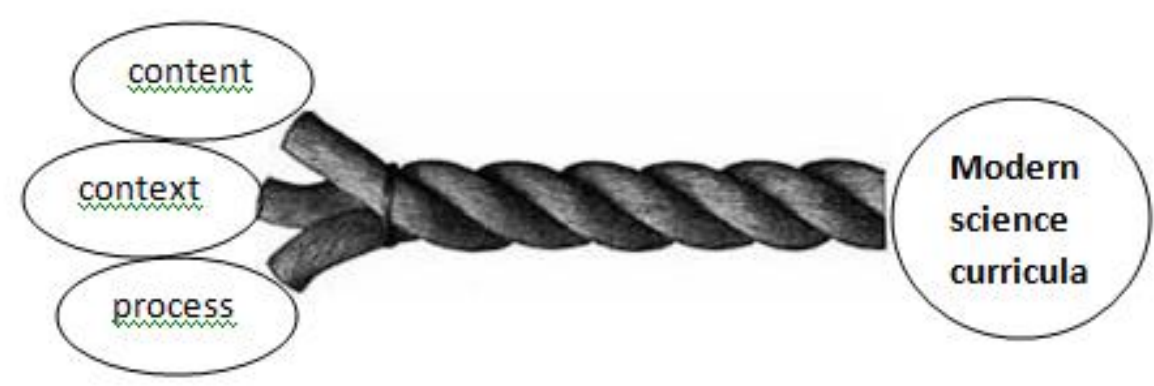

Figure 4 The three-fold cord of modern science education

I want to return in conclusion to my four main messages:

1. The chemistry/science curriculum needs a balance of all the main themes/emphases: content, process and context.

2. All aspects of the curriculum - content, pedagogy, outcomes and assessment must be integrated with each other and informed by science education research.

3. The curriculum must meet the needs of the majority (scientific literacy for future citizens) and also for the minority (science foundation for future scientists).

4. Curriculum development must involve teachers, scientists and science education researchers.

\section{Acknowledgements}

Thanks to Jan Lundell and the organisers of ECRICE for the invitation to speak at the conference. 


\section{References}

Adey, P., (2001) 160 years of science education: an uncertain link between theory and practice. SSR. 82(300) 41-48

Armstrong, H.E., (1925) The teaching of scientific method and other papers on education. $2^{\text {nd }}$ Edition. London: Macmillan

Ball, N. (1994) 'Richard Dawes and the teaching of common things, Educational Review, 17, 59-68

Bennett, J., \& Lubben, F. (2006) Context-based chemistry: The Salters approach. International Journal of Science Education, 28(9), 999-1015.

Brock, W.H., (1979) From Liebig to Nuffield: A Bibliography of the History of Science Education, 1839-1974. Studies in Science Education. 2(1), 67-99

Brock, W.H., (1992) Ch. 11 'How to teach chemistry' in the Fontana History of Chemistry, London: Fontana Press, 396-435

Chaddock, G.R., 1998 'Resisting education's fads', Christian Science Monitor, 90(190), B1, available at http://www.csmonitor.com/1998/o825/o82598.feat.feat.2.html, accessed 21/1/15

Cobern, W. W. , Schuster, D. , Adams, B. , Applegate, B. , Skjold, B. , Undreiu, A. , Loving, C. C. and Gobert,J. D.(2010) Experimental comparison of inquiry and direct instruction in science, Research in Science \& Technological Education, 28: 1, 81-96

Elder, L. and Paul, R. (2007) A Critical Thinker's Guide to Educational Fads, Dillon Beach, CA : Foundation for Critical Thinking

Eurydice, (2011) Science Education in Europe: National Practices, Policies, and Research. Brussels: European Commission [Online] http://eacea.ec.europa.eu/education/eurydice/documents/thematic_reports/133en.pdf Accessed 21/1/15

Gluckman, P. (2011) Looking Ahead: Science Education for the Twenty-first Century. Auckland: Office of the Prime Minister's Science Advisory Committee p. A-15 [Online] http://www.pmcsa.org.nz/wp-content/uploads/Looking-ahead-Science-education-for-thetwenty-first-century.pdf Accessed 21/1/15

Goodson, I.F. and March, C.J., (1996) Ch. 6 'Subject Histories: Science' in Studying School Subjects: A Guide, London: Falmer Press, p. 67-79

Hattie, J., (2008) Visible Learning: A Synthesis of Over 800 Meta-Analyses Relating to Achievement, London: Routledge

Herr, N., (2008) The Sourcebookfor teaching science. San Francisco: Wiley/Jossey-Bass.

Hodson, D., (1988) 'Science curriculum change in Victorian England: a case study of the science of common things' in (Ed.) I.F. Goodson, International Perspectives in Curriculum History, London and New York: Routledge

ICSU (2011). Report of the ICSU Ad-hoc Review Panel on Science Education. International Council for Science, Paris.

Layton, D., (1973) Science for the people: The origins of the school science curriculum in England, London: George Allen and Unwin

Matthews, M.R., (1994) Science Teaching: The Role of History and Philosophy. New York and London: Routledge

Matthews, M.R., (1994) Science Teaching: The Role of History and Philosophy. New York and London: Routledge

Millar, R., (2009) Twenty First Century Science encourages more students to continue the study of science London: Nuffield Foundation [Online]

http://www.nuffieldfoundation.org/sites/default/files/survey_report_-

_for_C21_website.pdf Accessed 21/11/15 
National Curriculum in England: science programmes of study, (2013) Department for Education. [Online] www.gov.uk/government/publications/national-curriculum-in-england-scienceprogrammes-of-study Accessed 19/1/15

National Science Learning Centre (2013) The future of STEM Education York: National Science Learning Centre. [Online] https://www.sciencelearningcentres.org.uk/media/filer_public/7f/d3/7fd32efo-a746452b-a681-8e5d15f5a1da/the_future_of_stem_education_-web.pdf Accessed 21/1/15

National Research Council. (2012) A Framework for K-12 Science Education: Practices, Crosscutting Concepts, and Core Ideas. Washington, DC: The National Academies Press [Online] http://www.nap.edu/catalog/13165/a-framework-for-k-12-science-education-practicescrosscutting-concepts Accessed 21/1/15

Osborne, J. (2007) Twenty First Century Science Education. Eurasia J. Math. Sci. \& Tech. Ed., 3(3), $173-184$

Ramirez, A., (2013) Save Our Science: How to Inspire a New Generation of Scientists TED books [Online] http://dukespace.lib.duke.edu/dspace/handle/10161/6775 Accessed 22/1/15

Ratcliffe, M., (2001) Science, Technology and Society in school science education. School Science Review, March 2001, 82(300) 84-92

Ravitch, D., (2015) 21st Century Skills: An Old Familiar Song. Available at: https://www.commoncore.org/maps/documents/reports/diane.pdf Accessed 21/1/2015

Roberts, D.A., (1982) Developing the Concept of "Curriculum Emphases" in Science Education. Science Education 66(2): 243-260

Rocard Report, (2007) Science Education NOW: A renewed Pedagogy for the Future of Europe. Brussels: European Commission

RSC (2011) Global Frameworks for Chemistry Education for the 11-14 and 14-18 age ranges. London: Royal Society of Chemistry [Online] http://www.rsc.org/images/DEVELOPING\%20A\%20GLOBAL\%20FRAMEWORK\%2OFOR \%20CHEMISTRY\%20EDUCATION_tcm18-207914.pdf Accessed 21/1/15

The Royal Society (2014) Vision for Science and Mathematics Education London: Royal Society [Online\} https://royalsociety.org/education/policy/vision/Accessed 20/1/15

Royal Society of New Zealand (2012) The future of science education in New Zealand. Wellington, NZ: Royal Society of New Zealand [Online] http://assets.royalsociety.org.nz/media/FutureScience-Education-Oct-2012.pdf Accessed 21/1/15

Tomei, A., (2012) 'I do and I understand: 50 years of curriculum development.' [Online] http://www.nuffieldfoundation.org/sites/default/files/files/Anthony_Tomei_speech_8_a y_2012.pdf Accessed 21/1/15

Van Berkel, B. (2005) The Structure of School Chemistry. PhD Thesis Utrecht: University of Utrecht.

Wallace, J. (1972) Science Teaching in Irish Schools 1860-1970. Irish Journal of Education. 6(1) 5063 